\title{
Comparison of feeding habits and physical activity between eutrophic and overweight/obese children and adolescents: a cross sectional study
}

\author{
Carlos Alberto Nogueira-de-Almeida ${ }^{1 *}$, Lara Aquino Ferreira Pires $^{2}$, Jordan Miyasaka ${ }^{2}$, Vanessa Bueno $^{2}$, Juliana Mathias \\ Netto Khouri ${ }^{2}$, Marianna Lorenzo S. Ramos ${ }^{2}$, Yara Cristina Ceccato ${ }^{2}$, Vivian Costa ${ }^{2}$, Francisco de Assis Maia Júnior ${ }^{2}$ \\ ${ }^{1} \mathrm{MD}$, MSc, PhD, Full Professor of Universidade de Ribeirão Preto (Unaerp), Ribeirão Preto, SP, Brazil \\ ${ }^{2} \mathrm{MD}$, Resident Physician, Unaerp, Ribeirão Preto, SP, Brazil
}

Study conducted at Universidade de Ribeirão Preto (Unaerp), Ribeirão Preto, SP, Brazil

Article received: $8 / 18 / 2014$ Accepted for publication: 8/26/2014 *Correspondence: Address: Rua Eugênio Ferrante, 170 Jd. Nova Aliança Sul Ribeirão Preto, SP - Brazil Postal code: $14027-150$ dr.nogueira@me.com

http://dx.doi.org/10.1590/1806-9282.61.03.227 Conflit of interest: none

\section{SUMMARY}

Objectives: it is broadly accepted, but little explored, that obese children practice less physical activity and eat more. This study has the objective of comparing feeding habits and physical activity between eutrophic and overweight/obese children and adolescents.

Methods: 126 students with ages ranging from 6 to 18 years were evaluated. Eutrophic and overweight/obese students were compared according to calorie intake, macro and micronutrients, prevalence of physical inactivity and ingestion of micronutrients.

Results: differences were observed in the amount of calories ingested per unit of BMI (eutrophic, 97.6, and overweight/obese, 70.5, $\mathrm{p}=0.0061$ ), as well as in calcium intake (eutrophic, 546.2, and overweight/obese, 440.7, $\mathrm{p}=0.0366$ ). Both groups presented sedentarism, as well as a high prevalence of micronutrient intake deficiency, especially calcium and vitamins A, E, and C, but with no difference observed between eutrophic and overweight/obese subjects.

Conclusion: energy and macronutrients consumption, as well as physical activity, were similar between eutrophic and overweight/obese. Calcium intake was lower in the overweight/obese group and the ingestion of vitamin $\mathrm{C}$ was lower in the eutrophic group. These results demonstrate the importance of considering all etiologic factors that may lead to obesity, so that new strategies for prevention and control may be added to traditional interventions.

Keywords: obesity, overweight, sedentary lifestyle, food consumption, micronutrients, health education.

\section{INTRODUCTION}

Brazil is going through a phase of nutritional transition where an important reduction in the percentages of undernourished children is observed, as well as a progressive increase, in the last decades, in the prevalence of excess weight. Data from the Research Project on Family Budgets (Pesquisa de Orçamentos Familiares, POF 2008-2009) ${ }^{1}$ demonstrate that for children from five to nine years old, the prevalence of overweight/obesity raised from 13.8\% (boys) and $10.4 \%$ (girls) to 51.4 and $43.8 \%$, respectively, and among adolescents it raised from $20.8 \%$ (boys) and $18.1 \%$ (girls) to 27.6 and $23.4 \%$, respectively. Obesity is a disease that originates from a combination of genetic and environmental factors. In the first group, we highlight the genes that predispose to greater appetite, to reduced satiety and to greater fat deposition, among other factors; in the second category, we basically include obesogenic environment, encompassing sedentarism and a high offer of food. Considering the relatively short time it took for the obesity epidemic to settle, it is unlikely that significant changes in the genetic material of the population have occurred, but the processes of metabolic programming and epigenetic inheritance may influence the phenotypic expression. In parallel, environmental influences may be exerting an important role, especially concerning the pattern of physical activity and food intake. 
In this sense, although it seems evident that overweight and obese children most likely practice less physical activity, ingest more food, and eat less healthy food than eutrophic children, this aspect has been little explored in the scientific literature, with sometimes conflicting results. ${ }^{2,3}$ The Helena study, for instance, with 2,176 adolescents from many cities in Europe, demonstrated that those physically more active did not eat better than the sedentary ones, concluding that there was no relation between the option of being more active and eating adequately. ${ }^{4} \mathrm{~A}$ representative study of the French adolescent population between 11 and 15 years of age, demonstrated a negative association between the practice of moderate or vigorous physical activities and excess weight. ${ }^{3}$ In California, researchers evaluated whether the presence of fast-food stores close to schools would lead to a higher prevalence of obesity, and found no such correlation. ${ }^{5}$ In Brazil, a study conducted in Salvador with adolescents between 10 and 14 years of age found a correlation between obesity and physical inactivity in boys only. ${ }^{6}$ An American study that evaluated diet and the use of computers for recreation demonstrated that excessive use of such equipment lead to inadequate diet, therefore, to excess weight, but the effect disappeared when the time spent using a computer was not taken into account. ${ }^{7}$ An American interventional study, case control, demonstrated that it is possible to improve children's diets by means of feeding education at home, but no reduction in the prevalence of obesity was observed among those who began to eat more fruits and vegetables, besides other nutrients considered important for good health. ${ }^{8}$

Many facilities have been conquered by modern men, such as more access to food and less physical effort, privileging intellectual activities, and those will most likely be embedded in the reality of human beings lives from now into the future. On the other hand, there is a speculation that such achievements may imply an increase in morbidity and mortality due to excess adiposity. ${ }^{9}$ Therefore, it is highly relevant to understand the true role of the new eating habits and physical activity patterns on the growing prevalence of obesity among children and adolescents. In order to contribute to this discussion, this study intended to compare eating habits and the pattern of physical activity of eutrophic and overweight/obese children and adolescents of a school in the city of Ribeirão Preto, SP, Brazil.

\section{Methods}

For this study, all children and adolescents regularly registered at the E.E.P.S.G. Dr. Francisco da Cunha Jun- queira, in the Bonfim Paulista District, Ribeirão Preto, state of São Paulo, Brazil, were considered. This school admits students from the first grade of elementary school to the senior year of high school. Since it is the only school in that district, it is considered that it serves people of all social classes. Inclusion criteria were: age between 6 and 18 years, informed consent signed by the parents, and BMI z-score between -2 and 1 . Exclusion criteria were: diseases that interfered in growth or anthropometry, diseases that demanded special diet, refusal to participate, and impossibility to practice physical activity. Once those criteria were met, the study group consisted of: 461 children as the total universe of eligible children; of those, 288 did not hand back the informed consent signed; 12 refused to participate after having brought back the informed consent signed; 3 were excluded due to neurologic disease or the presence of a cast for immobilization; 30 were excluded during the study because not all the data proposed was achieved; 2 were excluded due to a BMI $z$-score less than -2 . Consequently, the actual study group included 126 subjects, and, from each of them, the following data were collected: full name, date of birth, gender, weight, height, feeding habits, and level of physical activity.

Weight and height were measured according to international recommendations, and the body mass index (BMI) was calculated in order to assess nutritional status..$^{10}$ Only those with BMI z-score between -1 and 2 participated in the study, according to the inclusion criteria, using the World Health Organization height and weight charts. ${ }^{11}$ Food habits were assessed by means of a food diary handed to the participant to be filled at home in two pre-determined days, Wednesdays and Sundays, and subsequently delivered to one of the researchers with whom the data was checked and validated. The information was then fed into the Nutwin software ${ }^{12}$ where it was analyzed in regard to the composition of macro and micronutrients; intake adequacy was evaluated according to the dietary reference intakes (DRI).$^{13}$ To evaluate physical activity, the short version of the standardized international physical activity questionnaire (IPAQ) ${ }^{14}$ questionnaire was used, handed out to be filled at home and brought back to one of the researchers, with whom data was checked and validated. The decision to analyze the self-assessment questionnaire in its short version was due to the fact that it is the most suggested version for young populations. This version has eight open questions and their answers enable the estimation of the time used per week in different dimensions of physical activity (walks, and moderate and intense physical effort), as well as physical inactivity 
(sitting). For that purpose, the duration (minutes/day) reported by the children as answers to the questions presented in the IPAQ was multiplied by frequency (days/ week). The results were analyzed according to the standardized template and the participants classified in two groups: sedentary (when classified as sedentary or insufficiently active) and active (when classified as active or very active).

Data collection was blind; therefore, the person responsible for anthropometry and for the questionnaires was not aware of the nutritional classification of the subjects. Only after all data had been collected and inserted in the tables, the two groups were stratified as eutrophic ( $\mathrm{n}=73$, BMI $\mathrm{z}$-score between -2 and 1 ), and overweight/ obese ( $\mathrm{n}=53$, BMI z-score above 1$)$. An initial statistical evaluation was conducted in order to check whether the groups were homogeneous. Eutrophic and overweight/ obese subjects were, then, compared in two ways using the computer program Graphpad: ${ }^{15}$ 1) according to the distribution of calorie intake, macro and micronutrients, by Mann-Whitney test; 2) according to the distribution of the prevalence of sedentarism and the deficient ingestion of micronutrients using the Fischer's exact test, in this case, for comparison, the most recent Brazilian data on personal feeding habits, as described in the Research Project on Family Budgets (POF 2008-2009) was also presented. ${ }^{1}$

The research was approved by the Ethics in Research Committee of the University of Ribeirão Preto under number $103 / 2011$.

\section{ResULTS}

The percentage of girls amongst the eutrophic subjects was $58.9 \%$ and amongst obese subjects, $64.2 \%$ with no difference in gender distribution between the two groups $(p=0.5832$, Fischer's exact test). The mean age in the eutrophic group was 10.1 years, and in the obese group, 9.5 years, with no difference between the two groups $(\mathrm{p}=0.1629$, Mann-Whitney test).

Table 1 depicts the distribution of the medians and confidence intervals (CI) for calories, macro and micronutrient intake between groups. There was no statistical difference in most of the evaluations, except for the amount of energy ingested per BMI unit, and calcium intake, higher for the eutrophic subjects, as well as vitamin $\mathrm{C}$ intake, higher amongst the overweight/obese subjects.

Table 2 depicts the distribution of the prevalence of sedentarism and of deficient ingestion of micronutrients in the groups, no statistical difference being found in any of the comparisons done. Both groups reported little physical activity, more than $1 / 3$ of all the subjects evaluated being considered as sedentary or insufficiently active. In regard to minerals, although no difference was found between the groups, calcium intake was below the recommended level in more than $90 \%$ of all children and adolescents evaluated. Vitamins A, E and C were the most frequently inadequate. Compared to the POF 2008-2009 ${ }^{1}$ data, the micronutrients with the most concerning results in this study, such as calcium and vitamins A, E and $\mathrm{C}$, also had a high prevalence of inadequate intake.

TABLE 1 Distribution of medians and confidence intervals $(\mathrm{Cl})$ for intake of calories, macro and micronutrients in the groups of eutrophic and overweight/obese children and adolescents.

\begin{tabular}{|c|c|c|c|}
\hline & Eutrophic median $(\mathrm{Cl})$ & Overweight/obese median $(\mathrm{Cl})$ & $\mathrm{p}^{*}$ \\
\hline Energy (cal) & $1637.9(1581.8-1970.2)$ & $1771.5(1580.4-1916.3)$ & 0.7036 \\
\hline Energy (cal) per BMI unit $\left(\mathrm{kg} / \mathrm{m}^{2}\right)$ & $97.6(92.2-112.5)$ & $70.5(72.2-90.8)$ & 0.0061 \\
\hline Carbohydrates (g) & $227.9(213.3-272.6)$ & $229.1(212.5-264.8)$ & 0.8841 \\
\hline Proteins (g) & $77.4(71.5-89.0)$ & $74.8(68.7-83.7)$ & 0.7220 \\
\hline Lipids (g) & $46.5(45.5-59.7)$ & $55.7(46.1-61.8)$ & 0.5206 \\
\hline Zinc (mg) & $9.2(9.0-11.5)$ & $9.7(9.2-11.6)$ & 0.4798 \\
\hline Calcium (mg) & $546.2(517.2-673.9)$ & $440.7(404.4-523.4)$ & 0.0366 \\
\hline Iron (mg) & $12.3(12.4-15.8)$ & $12.7(12.2-15.3)$ & 0.8705 \\
\hline Magnesium (mg) & $245.2(229.2-277.1)$ & $225.3(216.4-279.7)$ & 0.4541 \\
\hline Vitamin A (microgram retinol) & $270.0(280.3-442.2)$ & $203.3(199.6-320.7)$ & 0.0614 \\
\hline Vitamin E (microgram alphaTE) & $2.6(2.4-3.5)$ & $2.1(2.5-4.5)$ & 0.8958 \\
\hline Vitamin C (mg) & $19.4(30.5-55.9)$ & $38.1(44.6-77.3)$ & 0.0166 \\
\hline Vitamin B12 (microgram) & $3.5(1.6-11.5)$ & $3.8(3.2-4.6)$ & 0.7858 \\
\hline Vitamin B6 (mg) & $1.1(1.2-1.7)$ & $1.2(1.1-1.4)$ & 0.7706 \\
\hline
\end{tabular}

* Mann-Whitney Test. 
TABLE 2 Distribution of the prevalence of sedentarism and deficient intake of micronutrients in the groups of eutrophic and overweight/obese children and adolescents and comparison with data of the Research Project on Family Budgets (POF 2008-2009)

\begin{tabular}{|c|c|c|c|c|c|}
\hline & Eutrophic & $\begin{array}{l}\text { Overweight/ } \\
\text { obese }\end{array}$ & $\mathrm{p}^{* *}$ & $\begin{array}{l}\text { POF } 2008-2009 \text { boys } \\
\text { (10 to } 13 \text { years old/14 to } \\
18 \text { years old) }\end{array}$ & $\begin{array}{l}\text { POF } 2008-2009 \text { girls } \\
\text { (10 to } 13 \text { years old } / 14 \\
\text { to } 18 \text { years old) }\end{array}$ \\
\hline Sedentarism* & $43.8 \%$ & $35.8 \%$ & 0.8129 & & \\
\hline Zinc & $34.2 \%$ & $20.8 \%$ & 0.1131 & $18.2 \% / 19.9 \%$ & $19.4 \% / 21.7 \%$ \\
\hline Calcium & $90.4 \%$ & $98.1 \%$ & 0.1372 & $96.4 \% / 95.1 \%$ & $97.2 \% / 97.3 \%$ \\
\hline Iron & $23.3 \%$ & $18.9 \%$ & 0.6617 & $8 \% / 11.5 \%$ & $7.4 \%$ / $24.2 \%$ \\
\hline Magnesium & $31.5 \%$ & $28.3 \%$ & 0.8443 & $36.8 \% / 78.2 \%$ & $42.4 \% / 84.7 \%$ \\
\hline Vitamin A & $61.6 \%$ & $75.5 \%$ & 0.1247 & $66.5 \% / 82 \%$ & $63.3 \% / 72.4 \%$ \\
\hline Vitamin E & $98.6 \%$ & $94.3 \%$ & 0.3089 & $99.2 \%$ / 99.9\% & $99.8 \%$ / 100\% \\
\hline Vitamin C & $65.8 \%$ & $43.1 \%$ & 0.0689 & $35.1 \% / 52.7 \%$ & $33 \% / 42.1 \%$ \\
\hline Vitamin B12 & $21.9 \%$ & $17.0 \%$ & 0.6515 & $7.6 \% / 11 \%$ & $4.8 \% / 11.7 \%$ \\
\hline Vitamin B6 & $27.4 \%$ & $18.9 \%$ & 0.2965 & $11.8 \% / 22 \%$ & $9.5 \% / 22.4 \%$ \\
\hline
\end{tabular}

\section{Discussion}

Obesity in childhood is becoming endemic, with fast and continuous growth almost all over the world. Generally speaking, it is unquestionable that the increase in fat storage is due to positive energy balance, situation where energy intake overcomes expenditure, part of the surplus energy being deposited. To explain why this phenomenon has been occurring in such a striking way for the past few years, many explanations may be brought forward but, generally speaking, all of them fit in three possibilities: ${ }^{16}$

- Energy intake increased.

- Energy expenditure decreased.

- A combination of both.

The decrease in energy expenditure also seems to be evident if we consider the facilities of the modern world that rendered daily activities less demanding in regard to the energy needed for them. ${ }^{17}$ Vasquez-Nava et al., in a recent study, evaluated children between 6 and 12 years of age in a Mexican urban area and found a prevalence of sedentarism of $57.2 \%{ }^{18}$ In Brazil, Cesquini et al., ${ }^{19}$ in a sample of 3,845 high school students, using the same instrument of the present study, the IPAQ-short version, ${ }^{14}$ found a prevalence of physical inactivity of $62.5 \%$. Higher caloric intake has been considered a reality, as food became more accessible, in terms of cost of acquisition logistic, and also more attractive. ${ }^{17}$ Nevertheless, this apparent simplicity of the phenomenon, shades much more complex situations, which deviate energy balance towards the side of storage, even in people who apparently do not eat more nor spend less energy than their peers. This study demonstrates this situation in a very clear way, as the overweight and obese children and adolescents evaluated, compared to the eutrophic subjects, presented practically identical intake and expenditure values. Some studies have been conducted on this topic and the results are often conflicting. Vieira et al., ${ }^{20}$ in a case-control study, comparing eutrophic adolescents with ages between 14 and 19 years to overweight/obese ones, did not find differences in energy or macronutrients intake, nor in physical activity. Assis et al., ${ }^{21}$ studying 120 adolescents, observed that those overweight/obese practiced more physical activity and ingested less milk, eggs, industrialized meat, sweets and soft drinks. Enes et al., ${ }^{22}$ evaluating 105 adolescents with ages between 10 and 14 years, did not find any difference when they compared the amount of physical activity, time spent watching TV, and energy, lipids, and fiber intake between eutrophic and overweight/obese adolescents. Velde et al. ${ }^{23}$ did a systematic review of prospective studies, which correlated energy balance and obesity and concluded that there is a strong inverse association between total physical activity and obesity, but did not find association with food intake or specific eating habits. The Australian study Look ${ }^{24}$ which followed 734 children from 8 to 12 years of age, concluded that obese children were less active but ingested less energy, fat, carbohydrates, and simple sugar. In a literature review, Sallis et al., ${ }^{25}$ evaluating 55 studies, concluded that it is not possible to establish a correlation between level of physical activity and body weight. In a recent sys- 
tematic review, Rauner et al., ${ }^{26}$ evaluating studies published after the year 2000, concluded that the correlation between physical activity and obesity remains unknown and that longitudinal studies cannot confirm the hypothesis that little physical activity leads to obesity.

When the ingestion of micronutrients was assessed in this study from the standpoint of inadequate intake, no difference was found between the groups, but the results are concerning as they reveal a much less than expected intake for minerals and vitamins, especially calcium, vitamins A, E and C. It is interesting to point out that such results are very similar to those obtained by the POF 2008-2009, ${ }^{1}$ which in a way points to the fact that the population studied is similar to the population of Brazilian subjects of the same age group.

It seems quite evident that, beyond the amount of food ingested, it is necessary to try to understand how the body uses and stores food. Likewise, how different people behave in regard to physical activity concerning interest, performance, caloric expenditure, capacity, among others, also has to be evaluated. A recent study demonstrates, for instance, that living with one of their separated parents may be per se a risk factor for sedentarism in obese children. ${ }^{18}$ In this sense, many factors have been described, which may be responsible for the origin and persistence of obesity, leading to positive energy balance, among which we emphasize:

1. Many types of genetic patterns: it is current knowledge that there is an important genetic component for obesity. It is possible that in the past the capacity of ingesting excess energy to increase the chance of surviving famine periods was advantageous evolution-wise. It is also believed that regular human energy expenditure then was significantly higher than today, in such way that most human beings had body weight below what was considered ideal in terms of reproductive aptitude. Therefore, natural selection favored polymorphisms that would determine more intake when there was more energy available. ${ }^{16}$ Monogenic inheritance is rare, but helps in the identification of multiple genes. ${ }^{27}$ In fact, studies of association in the whole genome have demonstrated a variety of genetic loci associated to the most common form of obesity, and more than 300 genetic loci potentially involved with obesity have been identified in human beings as well as in animals. ${ }^{16}$ Polymorphisms in the FTO gene, for instance, are associated to human obesity, leading to an increase in food intake and the preference for high energy food. ${ }^{28}$
2. Different thermogenic capacities: even slight inter-personal variations in thermogenesis can, in dynamic systems, and in the long run, be important for thermogenesis and maintenance of obesity.

3. Non-exercise activity thermogenesis, which refers to the individual capacity of generating heat, and therefore, spending energy, has been considered as derived from metabolic programming. ${ }^{29}$

4. Metabolic programming for the increase in the storage capacity: the fact that fetuses exposed to intra uterine nutritional restriction develop energy-sparing mechanisms to guarantee their survival is well recognized. When, after birth, the environment is no longer unfavorable and food offering is normal, the increased storage capacity becomes a risk for obesity. ${ }^{29}$

5. Viral contamination: animal trials have demonstrated that infections due to many viral agents can lead to obesity. Human studies demonstrate that the incidence of seroconversion for a specific virus may be significantly more frequent in obese adults and children than in normal subjects, and this fact has been more carefully studied in the last few years. ${ }^{30}$

6. Changes in bacterial flora: according to recent studies, gut microbiota may also play an important role in the prevalence of obesity, once changes in its composition have been observed in obese people, affecting body weight, insulin sensitivity, and lipid metabolism. $^{31}$

Exposure to endocrine disruptors: endocrine disruptors are environmental chemical compounds produced by human activity with the potential of mimicking or blocking hormone actions. Many of them can modulate lipid metabolism and adipogenesis, contributing for the genesis of obesity or its exacerbation. ${ }^{32}$

One aspect that deserves underscoring in this study is the fact that the total energy intake was similar in both groups, but when this intake was adjusted according to the BMI, it was higher in eutrophic subjects. The most likely explanation for this result concerns the difference in body composition for lean and obese subjects. It is likely that eutrophic subjects have a higher proportion of lean mass per BMI unit, and this is more metabolically active, therefore needing more energy intake. Since this is an unusual form of assessment, and it was not possible to compare the results with publications by other authors; new studies will be necessary in order to prove this hypothesis.

The individualized assessment of nutrients demonstrated that calcium intake was different between the groups, eutrophic subjects having consumed a signifi- 
cantly higher amount of this mineral, although in both groups there was a high prevalence of dietary inadequa$c y$. The scientific literature has recently suggested that low calcium intake may act as a factor that contributes to increase obesity. This was suggested by the Cardia study, ${ }^{33}$ which demonstrated that adequate intake of dairy products was inversely proportional to the onset of all signs and symptoms of insulin-resistance, including obesity. In order to explain the mechanism of action, Souza et al. ${ }^{34}$ state that dietary calcium is able to inhibit lipogenesis and stimulate the process of lipolysis. This action is enhanced when this mineral is obtained from dairy products. On the other hand, the absence of calcium in the diet promotes the increase of its concentration in adipose cells, favoring lipogenesis. Concurrently, this calcium inflow inhibits the phosphorylation of hormone-sensitive lipase, reducing fat oxidation. In obese subjects improvement in the parameters for the evaluation of adiposity has been demonstrated after the increase in dairy products intake. Heaney et al. ${ }^{35}$ evaluated 348 young women and observed that when calcium intake was below the 25 percentile, the prevalence of obesity was $15 \%$, but when calcium intake was within the recommendations, the prevalence dropped to $4 \%$. Freitas et al. ${ }^{36}$ in a review study, stated that most interventional studies suggest that calcium intake may favor the reduction of anthropometric measurements and improve body composition. They observed that the benefits are only detected when a regular low calcium intake ( $\approx 700 \mathrm{mg} /$ day or less) is increased to around 1,200 $1,300 \mathrm{mg} /$ day. Goldemberg et al. ${ }^{37}$ studied calcium intake and risk of obesity in adolescents and found significant differences in diet calcium densities between eutrophic and overweight/obese male subjects. They also found, for boys, an inverse relation between calcium ingestion and adiposity ( $\mathrm{r}=-0.488$ and $\mathrm{p}=0.0173$ ).

Vitamin C intake was higher among the overweight/ obese subjects. Even though the evaluation was not conducted considering food groups, one may presume that the main source of this vitamin was citric juices, much consumed in this region. In fact, the obesogenic role of fruit juices has been more and more recognized and their elimination from the diets of children and adolescents has been suggested as a way to prevent obesity. ${ }^{38}$

This study has some limitations. The method of obtaining dietary information by means of questionnaires is always subject to err, since it depends on the participants' cooperation. In the case of a study were people are compared considering their nutritional status, there is always the possibility of those overweight/obese not registering all their food, especially omitting food items know- ingly obesogenic. ${ }^{39}$ Another relevant aspect concerns the cross-sectional model of the study. Since the variables have been simultaneously evaluated in a single point in time, a cause-effect relation cannot be established. It is possible that food and physical activity, as observed in the study, which did not demonstrate differences between the groups, reflect only the current aspects, and that in the past, the now obese children and adolescents ingested more calories and practiced less physical activity than their eutrophic peers, therefore gaining weight. Lastly, we must emphasize that the data in this study reflect the reality of this community alone, and, although it does not have characteristics that differentiate it in an important way from other populations, it is not possible to extrapolate the data to the whole of subjects in the same age group.

\section{Conclusion}

This study has demonstrated that energy and macronutrient intake, as well as the amount of physical activity, was similar when eutrophic subjects were compared to overweight/obese subjects. In regard to micronutrients, similar intake was observed in both groups, except for calcium (lower in the overweight/obese group) and vitamin C (lower in the eutrophic group). Inadequacy in the intake of many micronutrients was observed, but there was no difference in the prevalence of such inadequacy in either group studied. These results demonstrate the importance of considering all etiologic factors that may lead to positive energy balance and obesity in order to associate new strategies of prevention and control to the traditional interventions.

\section{Resumo}

Comparação de hábitos alimentares e atividade física entre crianças e adolescentes eutróficos e portadores de sobrepeso/obesidade: estudo transversal.

Objetivos: considera-se, em geral, que crianças obesas praticam menos atividade física e consomem mais alimentos, mas esse aspecto tem sido muito pouco explorado. $\mathrm{O}$ presente estudo objetivou comparar a alimentação e o padrão de atividade física de crianças e adolescentes eutróficos e portadores de sobrepeso/obesidade.

Métodos: 126 estudantes com idades entre 6 e 18 anos foram avaliados por meio de antropometria, registro alimentar e grau de atividade física. Eutróficos e portadores de sobrepeso/obesidade foram comparados de acordo com a ingestão de calorias, macro e micronutrientes e de acordo com as prevalências de inatividade física e de ingestão deficiente de micronutrientes. 
Resultados: observou-se diferença na quantidade de calorias ingeridas por unidade de IMC (eutróficos 97,6 [92,2 112,5] e sobrepeso/obesidade 70,5 [72,2 - 90,8], p =0,0061) e na ingestão de cálcio (eutróficos 546,2 [517,2 - 673,9] e sobrepeso/obesidade 440,7 [404,4 - 523,4], p=0,0366). Os dois grupos apresentaram sedentarismo e elevada prevalência de deficiência na ingestão de micronutrientes, especialmente cálcio e vitaminas $\mathrm{A}$, E e $\mathrm{C}$, mas sem diferença entre eutróficos e portadores de sobrepeso/obesidade.

Conclusões: consumo de energia e de macronutrientes e grau de atividade física foram semelhantes, quando comparados indivíduos eutróficos com portadores de sobrepeso/obesidade. O consumo de cálcio foi menor no grupo sobrepeso/obesidade e o de vitamina $\mathrm{C}$ menor no grupo eutróficos. Esses resultados mostram a importância de considerar todos os fatores etiológicos que podem levar à obesidade a fim de que possam associar-se novas estratégias de prevenção e controle às intervenções tradicionais.

Palavras-chave: obesidade, sobrepeso, estilo de vida sedentário, consumo de alimentos, micronutrientes, educação saudável.

\section{REFERENCES}

1. IBGE. Pesquisa de orçamentos familiares 2008-2009 - Análise do consumo alimentar pessoal no Brasil. Rio de Janeiro: IBGE, 2011. Available at: http:// www.ibge.gov.br/home/estatistica/populacao/condicaodevida/ pof/2008_2009_analise_consumo/pofanalise_2008_2009.pdf.

2. Hare-Bruun H, Nielsen BM, Kristensen PL, Møller NC, Togo P, Heitmann BL. Television viewing, food preferences, and food habits among children: a prospective epidemiological study. BMC Public Health. 2011; 11:311.

3. Dupuy M, Godeau E, Vignes C, Ahluwalia N. Socio-demographic and lifestyle factors associated with overweight in a representative sample of 11-15 year olds in France: results from the WHO-Collaborative Health Behaviour in Schoolaged Children (HBSC) cross-sectional study. BMC Public Health 2011; 11:442.

4. Ottevaere C, Huybrechts I, Béghin L, Cuenca-Garcia M, De Bourdeaudhuij I, Gottrand F, et al. Relationship between self-reported dietary intake and physical activity levels among adolescents: the HELENA study. Int J Behav Nutr Phys Act. 2011; 8:8.

5. Howard PH, Fitzpatrick M, Fulfrost B. Proximity of food retailers to schools and rates of overweight ninth grade students: an ecological study in California. BMC Public Health. 2011; 11:68.

6. Souza CS RC, Assis AM, Fiaccone RL, Pinto EJ, Moraes LT. Association between physical inactivity and overweight among adolescents in Salvador, Bahia, Brazil. Rev Bras Epidemiol. 2010; 13(3):468-75.

7. Shi L, Mao Y. Excessive recreational computer use and food consumption behaviour among adolescents. Ital J Pediatr. 2010; 36:52.

8. Fulkerson JA, Rydell S, Kubik MY, Lytle L, Boutelle K, Story M, et al. Healthy Home Offerings via the Mealtime Environment (HOME): feasibility, acceptability, and outcomes of a pilot study. Obesity (Silver Spring). 2010; 18(Suppl 1):S69-74.

9. Finkelstein EA, Strombotne KL. The economics of obesity. Am J Clin Nutr. 2010; 91(5):1520S-4S

10. WHO. Physical status: the use and interpretation of anthropometry. Report of a WHO Expert Committee 1995. [Technical Reports Series n. 854]. Available at: http://www.who.int/childgrowth/publications/physical_status/en/.

11. de Onis M, Onyango AW, Borghi E, Siyam A, Nishida C, Siekmann J. Development of a WHO growth reference for school-aged children and adolescents. Bull World Health Organ. 2007; 85(9):660-7.

12. Anção M. Sistema de Apoio à Nutrição - NutWin. 2.5.ed. São Paulo: UNIFESP, 2002.
13. USDA. Dietary Reference Intakes. Food and Nutrition Information Center, 2012 [cited 2013 jul 2013]. Available at: http://fnic.nal.usda.gov/dietaryguidance/dietary-reference-intakes.

14. Guedes DP, Lopes CC, Guedes JERP. Reprodutibilidade e validade do Questionário Internacional de Atividade Física em adolescentes. Rev Bras Med Esporte. 2005; 11(2):151-8.

15. Motulsky H. GraphPad. 5.0.ed. La Jolla: GraphPad Software Inc, 2011.

16. Crocker MK, Yanovski JA. Pediatric obesity: etiology and treatment. Endocrinol Metab Clin North Am. 2009; 38(3):525-48.

17. Skelton JA, Irby MB, Grzywacz JG, Miller G. Etiologies of obesity in children: nature and nurture. Pediatr Clin North Am. 2011; 58(6):1333-54.

18. Vázquez-Nava F, Treviño-Garcia-Manzo N, Vázquez-Rodríguez CF, VázquezRodríguez EM. Association between family structure, maternal education level, and maternal employment with sedentary lifestyle in primary schoolage children. J Pediatr (Rio J). 2013; 89(2):145-50.

19. Ceschini FL, Andrade DR, Oliveira LC, Araujo Junior JF, Matsudo VK. Prevalence of physical inactivity and associated factors among high school students from state's public schools. J Pediatr (Rio J). 2009; 85(4):301-6.

20. Del Ciampo LA, Del Ciampo IRL, Vieira MV. Eating habits and practice of physical activity among eutrophic and overweight adolescents. Int J Nutrology. 2012; 5(1):22-7.

21. Assis CM, Quio VR, Rasseli JG, Cunha FGC, Salaroli LB. Hábitos alimentares e estado nutricional de jovens: um estudo comparativo. Nutrire. 2009; 34(1):15.

22. Enes CC, Pegolo GE, Silva MV. Influência do consumo alimentar e do padrão de atividade física sobre o estado nutricional de adolescentes de Piedade, São Paulo. Rev Paul Pediatr. 2009; 27(3):265-71.

23. Te Velde SJ, van Nassau F, Uijtdewilligen L, van Stralen MM, Cardon G, De Craemer M, et al. Energy balance-related behaviours associated with overweight and obesity in preschool children: a systematic review of prospective studies. Obes Rev. 2012; 13(Suppl 1):56-74.

24. Telford RD, Cunningham RB, Telford RM, Riley M, Abhayaratna WP. Determinants of childhood adiposity: evidence from the Australian LOOK study. PLoS One. 2012; 7(11):e50014.

25. Sallis JF, Prochaska JJ, Taylor WC. A review of correlates of physical activity of children and adolescents. Med Sci Sports Exerc. 2000; 32(5):963-75.

26. Rauner A, Mess F, Woll A. The relationship between physical activity, physical fitness and overweight in adolescents: a systematic review of studies published in or after 2000. BMC Pediatr. 2013; 13:19.

27. Xia Q, Grant SF. The genetics of human obesity. Ann N Y Acad Sci. 2013; 1281:178-90.

28. Karra E, O'Daly OG, Choudhury AI, Yousseif A, Millership S, Neary MT, et al. A link between FTO, ghrelin, and impaired brain food-cue responsivity. J Clin Invest. 2013; 123(8):3539-51.

29. Gardner DS, Rhodes P. Developmental origins of obesity: programming of food intake or physical activity? Adv Exp Med Biol. 2009; 646:83-93.

30. Yamada T, Hara K, Kadowaki T. Association of adenovirus 36 infection with obesity and metabolic markers in humans: a meta-analysis of observational studies. PLoS One. 2012; 7(7):e42031.

31. Stachowicz N, Kiersztan A. [The role of gut microbiota in the pathogenesis of obesity and diabetes]. Postepy Hig Med Dosw (Online). 2013; 67:288-303

32. Hatch EE, Nelson JW, Stahlhut RW, Webster TF. Association of endocrine disruptors and obesity: perspectives from epidemiological studies. Int J Androl. 2010; 33(2):324-32.

33. Pereira MA, Jacobs Jr DR, Van Horn L, Slattery ML, Kartashov AI, Ludwig DS. Dairy consumption, obesity, and the insulin resistance syndrome in young adults: the CARDIA study. JAMA. 2002; 287(16):2081-9.

34. Sousa AF, Poltronieri F, Marreiro DN. Role of calcium in obesity. Nutrire. 2008; 33(1):14

35. Heaney RP, Davies KM, Barger-Lux MJ. Calcium and weight: clinical studies. J Am Coll Nutr. 2002; 21(2):152S-5S.

36. De Oliveira Freitas DM, Stampini Duarte Martino H, Machado Rocha Ribeiro S, Gonçalves Alfenas RC. Calcium ingestion and obesity control. Nutr Hosp. 2012; 27(6):1758-71.

37. Goldberg TB, da Silva CC, Peres LN, Berbel MN, Heigasi MB, Ribeiro JM, et al. Calcium intake and its relationship with risk of overweight and obesity in adolescents. Arch Latinoam Nutr. 2009; 59(1):14-21.

38. Wojcicki JM, Heyman MB. Reducing childhood obesity by eliminating $100 \%$ fruit juice. Am J Public Health. 2012; 102(9):1630-3.

39. Burrows T, Golley RK, Khambalia A, McNaughton SA, Magarey A, Rosenkranz RR, et al. The quality of dietary intake methodology and reporting in child and adolescent obesity intervention trials: a systematic review. Obes Rev. 2012; 13(12):1125-38. 